\section{Las tres Marías}

The three Mary's

Se llama María N., tiene 83 años, vive sola, nunca se casó. Su único familiar vivo reside en una lejana ciudad. Hace dos años tuvo un ictus. Le ocasiona inestabilidad crónica. Sobrevive porque una vecina la cuida, le hace la compra y la limpieza, y frecuentemente le hace compañía y la invita a comer. Reingresa ahora por otra caída. Ha tenido suerte de no haberse roto la cadera. Estrictamente no precisa hospitalización pero está sola; un problema burocrático la ha privado de su pensión y se ha acentuado la pérdida de memoria y la inestabilidad. La Trabajadora Social y yo intentamos hallar una solución posible a una situación imposible. Al final, la acoge su abnegada vecina, mientras gestionamos una exigua ayuda domiciliaria.

Con un trasfondo de las terribles incursiones piratas del siglo XVII en las rías gallegas, Celso Emilio Ferreiro compuso su emocionante poema María Soliña. Lo dedica a esa mujer que había perdido marido y hermano en una de tales correrías. Acusada de brujería, en realidad por envidia y oscuros intereses económicos, paseó su "soidade" -hermoso y desolado término gallego- por las playas de Cangas del Morrazo. Rememoro su historia y la de la otra María cuando estalla periódicamente la polémica sobre hospitales con tecnologías de vanguardia pero incapaces de dar salida a enfermos crónicos abandonados socialmente. Rosalía de Castro recordaba las "viudas de vivos"-las esposas de emigrantes que quedaban en Galicia-, y las "viudas de muertos" -de los marineros desaparecidos en la mar. ¿Quién se acuerda hoy de las "viudas" de nuestro estado del "bienestar"?

También se llama María. Tras errar por media Europa, huyendo de persecuciones y barbaries, recala en Norteamérica. Problemas de inmigración le separarán definitivamente de su esposo. Ahora una hemiplejia la retiene inmovilizada. Una sobrina la atiende, pero su instante más preciado es aquel nocturno en que, junto al lecho, su ocupadísimo hermano le lee calmosamente pasajes de sus libros preferidos. Cuando los escucha en el idioma materno, su cuerpo olvida la pesadez y corretea libre, como cuando niña en su lejano país. A su muerte, su hermano, que se jactó en ocasiones de tener la piel más dura que un elefante para no ceder a las emociones, revelará con ojos húmedos que "no se atrevía a confesar lo mucho que la echaba de menos". Ella se llamaba María, pero todos la llamaban Maja. Su hermano se llamaba Albert Einstein.

Como Médico Internista, una de las expresiones que más odio escuchar a mis colegas especialistas es aquella de "ahora hazte cargo tú de este paciente porque yo no tengo más que hacerle".

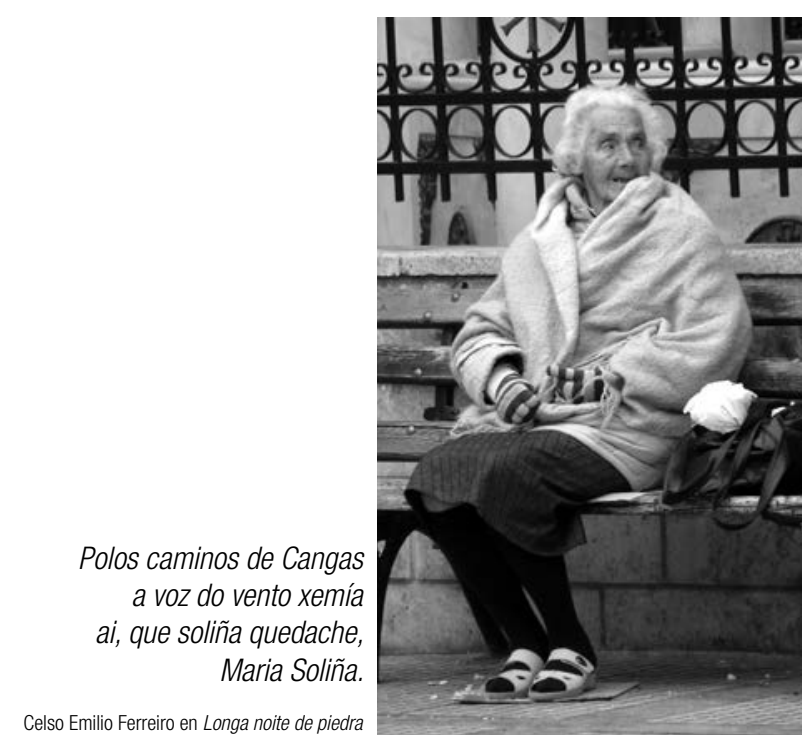

Así intentan traspasar aquellos pacientes, en muchas ocasiones tras largos años de ocuparse de su atención, cuando llega un momento en que sus dolencias parecen ya irreversibles. Puedo decir que casi siempre he aceptado tales traspasos, aunque en muchas ocasiones forzando a quien me hacía tales propuestas a seguir compartiendo la atención. Sin embargo, me parece tremendamente desolador que quienes han desarrollado una relación prolongada con dichos pacientes, no tengan ahora el valor y coraje de enfrentarse al momento más decisivo en la vida de otros seres humanos. Y si, llegado el ocaso de su vida, la Medicina no puede ofrecer ya curación, siempre puede brindar una voz amiga, un oído que escuche 0 alguien que permanezca en silencio, acompañando a los familiares en la aceptación de la pérdida del ser querido. Volvemos a necesitar personas que se encarguen de personas, es decir aquellas que recuperen la labor sempiterna del MÉDICO: que alivien, conforten, tranquilicen y se solidaricen con sus semejantes.

Siempre me gustó contemplar la constelación de Orión en las gélidas noches invernales. Las "tres Marías" de su cinturón se hacen compañía y parece que abrazan la tierra. Desearía que "mis" tres Marías no estuvieran ya solas. Celebro que Maja Einstein encontrara un alma gemela en sus postreros pasos. No puedo hacer ya nada por María Soliña, excepto emocionarme al leer su historia y "com-padecer" su soidade. Pero me gustaría ejercer con María N. ese oficio del corazón que constituye mi vocación de médico. Hasta que llegue el naufragio total de las palabras -como definía el poeta Valentín Paz Andrade a la muerte- intentar que mi voz y compañía fueran su consuelo. Y que éste brote de aquel corazón, del cual afirmaba Paracelso que "no existe corazón más grande que el corazón del médico".

\section{Julio Montes Santiago}

Servicio de Medicina Interna. Complejo Hospitalario Universitario Vigo. SERGAS. Vigo 